By FERNANDO PENALOSA

\title{
The Card Catalog: A Failure in Communication
}

$I^{\mathrm{F}}$ WE CONSIDER the library to be the heart of a university or college, or as the community's information center, then the card catalog might be considered the heart of the library, or better still, its brain. It is a massive brain, constructed out of tens of thousands of brain efforts on the part of several generations of catalogers. Yet the card catalog is an inert thing until acted upon by the brain of the user. If an incredible amount of mental effort goes into the making of the catalog, an even more incredible amount of mental effort must be expended by the library patron in its decipherment and use.

It is a curious thing that the librarians engaged in producing this all-important library tool have, in most instances, little contact with the people for whom it is supposedly designed. It seems that in this situation students of the communication process would find much of a disturbing nature. The library is rightly considered a medium not of mass communication, but of individualized communication. In the latter, the communication process is characterized by the message's sender and receiver standing in each other's physical presence. As the message is being sent, there is "feedback" from the receiver to the sender, who then varies his message according to results being obtained. A good example of this face-to-face communication is a private conversation.

How, then, do these concepts of the

$M r$. Peñalosa is instructor, School of Library Science, University of Southern California. communication process apply to the functions of the card catalog? The cataloger or catalog department is the sender of a very vital message: how to find materials in the library. The catalog users are the receivers, the audience, that struggles at comprehending the message. Sometimes the message is not understood, and the audience goes away unsatisfied; or the message may be misunderstood and the audience is deceived or frustrated; or the message may be overlooked or ignored, and the audience is cheated. But only in the rarest of instances is there any feedback to the communicator. Hence the message continues to be phrased in the same terms, and is designed often for an audience that exists only in the cataloger's imagination.

What, then, is the audience for the library's card catalog? It consists of two very different groups: the library staff, a relatively homogeneous group; and the library patrons, an extremely heterogeneous group. Even the most casual observer will recognize that the ways in which the two groups cope with and make use of the card catalog will diverge greatly.

Let us consider first the library patrons. The difficulties experienced by laymen in using subject headings, cross references, corporate entries, etc. are well known and need not be described here. However, the nature of the bibliographic information on the card itself is perhaps the most confusing of all to the general catalog user. Certain problems can be illustrated by some points brought out in a study of catalog use made at the Denver Public Library and the University of 
Denver Library. ${ }^{1}$ The study involved interviewing one hundred students at each of the two libraries over a period of several months.

The part of the catalog most used by students was the part including the heading (subject or added entry), author and title. The only bibliographic items used extensively on the cards were the title, author, date of publication and Library of Congress tracings for subject headings. Seventy-four per cent of all students used the title, 23.5 per cent the author, 22 per cent the date of publication and 11 per cent the Library of Congress subject tracings. All other items were used by 5 per cent or less of the students. Sixty-nine per cent of the students at the University of Denver Library catalog and 76 per cent of those at the Denver Public Library catalog used only one or two items each.

In addition to the heading each interviewee was found to use an average of only 1.6 bibliographic items as aids in selecting a particular book. It was noteworthy, when one considers that tracings are thought of as being primarily for the use of the cataloger, that 11 per cent of all students interviewed used LC subject tracings to find out what the book was about and that at least one student complained of the absence of subject tracings on typewritten cards.

The reason for such limited use of the catalog is probably that the students, intent on a specific title or subject, usually read only the heading and title, which was then the only information that they needed to help them decide on the book. The notion that the title or subtitle was a description or annotation of the book was quite prevalent, especially when the subtitle was long. These were undoubtedly cases of wishful thinking. Students also had difficulty in finding wanted information on catalog cards. Thus many stu-

\footnotetext{
1 Fernando Peñalosa, "An Investigation of the Manner in Which Students of the University of Denver Use the Card Catalog" (M.A. Thesis, University of Denver, 1949).
}

dents complained of information lacking on the card, only to have the writer show them such information on the card.

When the students were asked if there was any additional information about the particular book in question that did not appear on the catalog card that they would like to have had in that particular instance, 18 per cent of all those interviewed replied that they wished more information about the contents of the book. Over 13 per cent stated specifically that they would have wanted an annotation for the book in question printed or typed on the card, although they did not necessarily use the word "annotation."

The main conclusion of the study, then, insofar as the card itself is concerned, would be that from the viewpoint of patrons, catalog cards contain entirely too much bibliographic information and not enough information about the contents of books. If this is true for university students, it must be even more so for the general public, most of whom have not enjoyed the advantages of an advanced education. Other studies of catalog use which have been made have come to substantially the same conclusions. ${ }^{2}$

Now what about the other audience for the catalog, the library staff? Since making the above-mentioned study, the writer has had occasion to use the catalog intensively in acquisitions work, cataloging, and in work with the public. It is the writer's firm conviction that less bibliographic information on catalog cards would greatly hamper the library staff in its work. Particularly is this true in acquisitions work involving positive identification of titles suggested for purchase or for acceptance as gifts. It further goes without saying that catalog librarians would feel themselves lost without sufficient bibliographic information on cards for books already in the library. Thus,

\footnotetext{
${ }^{2}$ A good summary of studies of catalog use is Carlyle J. Frarey, "Studies of Use of the Subject Catalog; Summary and Evaluation," in M. F. Tauber, ed., The Subject Analysis of Library Materials (New York: School of Library Service, Columbia University, 1953), p. 147-166.
} 
the suspicion aroused in the study above, namely, that catalog cards are made primarily for bibliographers and librarians, is borne out by the fact that in most cases the cards are admirably suited for their purposes!

Returning once more to the jargon of communication we might say that catalogers through the cards they produce are communicating effectively to an audience of bibliographers, bibliophiles and librarians. They are trying to reach two very different audiences with the same channel, hence fail where one audience is concerned. The failure has arisen because where two different audiences are concerned, two different types of channels are called for. The commercial agencies of communication grasped this elementary truth long ago, and produce different types of radio and television programs, magazines, etc. to reach different audiences. In plain language, then, what is required is two kinds of cataloging.

What precisely would be involved? First, a public card catalog devoid of superfluous bibliographic information but containing on each card a short annotation indicating the scope of the work and the reader for whom it is designed. In many cases the annotation need not consist of more than a sentence of two. Second, an official author catalog, with very complete bibliographic data, conveniently located for staff use. A library that might desire to change over to a dual system should proceed slowly and with caution. Thus first on the agenda would be a survey or a series of surveys to determine the extent to which the patrons of that particular library use the bibliographic information on catalog cards. On this basis the library could decide what items would appear on public cards under the new system .

While individual libraries naturally will devise the most suitable methods for converting to the dual system, the prime consideration is to proceed with caution, and as local conditions demand or permit. By all means, use printed cards where possible, LC cards in the official catalog and Wilson cards in the public catalog. The H. W. Wilson Company has pioneered in progressive cataloging procedures and we librarians have much to learn from the principles embodied in its cards. Perhaps the Wilson Company could even be induced to expand its coverage if there were enough demand for this type of card from libraries.

Essential to the functioning of a dual cataloging system would be a form of cooperation much closer than that which generally prevails between the technical and the public services. Bibliographic information will be compiled by catalogers, but the annotations for the public cata$\log$ will be composed by pubilc service people, such as readers advisers or reference librarians, who work with the public and understand their guidance needs. Such an arrangement, in fact, would necessitate considerable reorganization of staff and routines, and would, this writer fervently hopes, contribute toward breaking down the artificial barriers that exist between those engaged in processing materials and those engaged in serving the public directly. 